\title{
Effect of divalent ions on cariogenic biofilm formation
}

\author{
Elena Laura Steiger ${ }^{1 \dagger}$, Julia Rahel Muelli ${ }^{1 \dagger}$, Olivier Braissant ${ }^{2}$, Tuomas Waltimo ${ }^{1}$ and \\ Monika Astasov-Frauenhoffer ${ }^{3^{*}}$ (i)
}

\begin{abstract}
Background: Divalent cations are able to interact with exopolysaccharides (EPS) and thus are capable to modify the structure and composition of dental biofilm. At the moment, little is known about the adsorption of metals by cariogenic EPS; thus, the aim of the present study was to evaluate the effect of divalent ions (calcium, magnesium, and zinc) on the growth and biofilm formation of mutans streptococci and on the dissolution of hydroxyapatite as well as to investigate their binding to the bacterial EPS.
\end{abstract}

Results: S. mutans strains used in this study show the highest tolerance towards calcium of the ions tested. Growth parameters showed no differences to control condition for both strains up to $100 \mathrm{mM}$; revealing natural tolerance to higher concentration of calcium in the surroundings. Although excessive levels of calcium did not impair the growth parameters, it also did not have a positive effect on biofilm formation or its binding affinity to EPS. Magnesium-saturated environment proved to be counterproductive as strains were able to dissolve more $\mathrm{Ca}^{2+}$ from the tooth surface in the presence of magnesium, therefore releasing excessive amounts of $\mathrm{Ca}^{2+}$ in the environment and leading to the progression of the disease. Thus, this supports the idea of self-regulation, when more $\mathrm{Ca}^{2+}$ is released, more calcium is bound to the biofilm strengthening its structure and however, also less is left for remineralization. Zinc inhibited bacterial adhesion already at low concentrations and had a strong antibacterial effect on the strains as well as on calcium dissolution; leading to less biofilm and less EPS. Additionally, $\mathrm{Zn}^{2+}$ had almost always the lowest affinity to all EPS; thus, the unbound zinc could also still remain in the surrounding environment and keep its antimicrobial properties.

Conclusion: It is important to maintain a stable relationship between calcium, magnesium and zinc as excessive concentrations of one can easily destroy the balance between the three in cariogenic environment and lead to progression of the disease.

Keywords: Caries, Biofilm, Mutans streptococci, Divalent ions

\section{Background}

Dental caries is one of the most frequent infectious multifactorial diseases worldwide, characterized as a progressive dissolution and demineralization of tooth structure; when left untreated it can lead to an impaired

\footnotetext{
* Correspondence: m.astasov-frauenhoffer@unibas.ch

${ }^{\dagger}$ Elena Laura Steiger and Julia Rahel Muelli contributed equally to this work. ${ }^{3}$ Department Research, University Center for Dental Medicine (UZB), University of Basel, Mattenstrasse 40, 4058 Basel, Switzerland

Full list of author information is available at the end of the article
}

quality of life [1-3]. The development depends on various aspects e.g. personal and social-economic factors (e.g. education, knowledge, behavior, income), genetic and environmental factors (e.g. pH-value, buffer capacity, composition and flowrate of saliva) [4]. Furthermore, studies have shown that frequent intake of high sugar content food and beverages increases the personal caries risk [5-7]. In such conditions, acidogenic bacteria, like mutans streptococci, are capable of generating an acidic shift in the dental biofilm which results in the

(C) The Author(s). 2020 Open Access This article is licensed under a Creative Commons Attribution 4.0 International License, which permits use, sharing, adaptation, distribution and reproduction in any medium or format, as long as you give appropriate credit to the original author(s) and the source, provide a link to the Creative Commons licence, and indicate if changes were made. The images or other third party material in this article are included in the article's Creative Commons licence, unless indicated otherwise in a credit line to the material. If material is not included in the article's Creative Commons licence and your intended use is not permitted by statutory regulation or exceeds the permitted use, you will need to obtain permission directly from the copyright holder. To view a copy of this licence, visit http://creativecommons.org/licenses/by/4.0/ The Creative Commons Public Domain Dedication waiver (http://creativecommons.org/publicdomain/zero/1.0/) applies to the data made available in this article, unless otherwise stated in a credit line to the data. 
demineralization of the hard tissues of the teeth $[1-3,8$, 9]. This manifestation occurs only if there is an imbalance between the protective and the pathogenic factors inside the oral biofilm. Nevertheless, the progression can only be arrested by preventing further biofilm formation [10]. Sucrose is the most commonly consumed carbohydrate and has proven to be very cariogenic [9, 11-13], especially in combination with a microflora that contains high numbers of Streptococcus mutans [14, 15]. Moreover, also monosaccharides, like glucose, fructose, galactose, or disaccharides, like lactose and maltose, play a significant role in the development of caries $[7,13]$.

In most biofilms, and hence in dental plaque, the microbes make up only for about $10 \%$ of the dry mass while rest is extracellular matrix [16]. Decisive parts of the matrix in the dental biofilm are the extracellular polysaccharides (EPS), which in caries lesions are predominantly produced by S. mutans [17]. The development of EPS depends on various factors such as $\mathrm{pH}$, temperature, time, and the composition of the medium, in which the sources of carbon, nitrogen, and divalent ions play an important role [18]. Since EPS contains negative charged functional groups and has the potential in removing heavy metal ions from solutions, there is the possibility that divalent ions can bind EPS as well and therefore change its whole structure and function [19].

The growth of the biofilm, and thus the aggregation of EPS, depends on specific environmental signals [20]. The study of Cheng et al. showed that $\mathrm{SnF}_{2}$-containing toothpastes reduce the amount of EPS in the dental plaque and consequently change the entire structure of the cariogenic biofilm s due to a change in the metabolism of $S$. mutans after the uptake of tin [21]. Since EPS is produced by streptococcal glucosyltransferases, it can be assumed that its development can be reduced and thus, the growth of biofilm stopped [22]. Therefore, it is presumed that the development or the progression of dental caries can be modified by the application of certain cations. Among those ions, it is expected that $\mathrm{Ca}$, $\mathrm{Mg}$ and $\mathrm{Zn}$ might have an important role as they are naturally present in the upper surfaces of teeth.

Calcium is capable to affect the biofilm production through diverse mechanisms [20]. High concentrations of $\mathrm{Ca}^{2+}$ have shown to enhance biofilm formation in a dental lesion [8]. The calcium in teeth can act as a mineral buffer; however, when released, it reduces the mineral dissolution [23]. Consequently, it can be concluded that the demineralization can be limited, and also that the dental biofilm plays a considerable role in the calcium regulation $[8,24]$.

Similarly, magnesium levels in teeth tend to decrease with age, leading to a change in the mineralized tissues and thus a reduction in its physical properties such as hardness [25]. In order to prevent this, dentifrices containing magnesium have been developed to protect the teeth from external acids, ultimately resulting in an increased hardness of the whole tooth framework [25, 26].

Finally, zinc is also a cation that can lead to changes in the development and progression of dental lesions. It is naturally found as a trace element in saliva (mean concentration $3.95 \mathrm{mg} / \mathrm{L}$, [27]), dental biofilm and also in the teeth $[28,29] . \mathrm{Zn}^{2+}$ is able to support the control of biofilm development, reduce malodour and also inhibit calculus formation [29]. Thus, zinc oxide and zinc citrate are often present in toothpastes or in mouth rinses as they inhibit biofilm formation by reducing glucan synthesis; however, that cannot prevent the formation of tooth decays on its own [30].

Divalent cations are able to interact with EPS and thus are capable to modify the structure and composition of dental biofilm. At the moment, little is known about the adsorption of metals by cariogenic EPS, as it depends on numerous factors. In addition, the analysis of the multiple interactions between EPS and the divalent ions is difficult because of the low availability of the predictive tools [31].

Thus, the aim of the present study was to evaluate the effect of divalent ions (calcium, magnesium, and zinc) on the growth and biofilm formation of mutans streptococci and on the dissolution of hydroxyapatite as well as to investigate their binding to the bacterial EPS.

\section{Results \\ Effect of divalent ions on the growth of mutans streptococci}

The effect of divalent ions on the growth of $S$. mutans was investigated by using three different dietary sugars (glucose, sucrose and fructose) and three different types of divalent ions $\left(\mathrm{Ca}^{2+}, \mathrm{Mg}^{2+}\right.$ and $\left.\mathrm{Zn}^{2+}\right)$ in combination with chloride $\left(\mathrm{CaCl}_{2}, \mathrm{MgCl}_{2}\right.$, and $\left.\mathrm{ZnCl}_{2}\right)$.

Growth rate (Fig. 1) was significantly affected for the type strain of $S$. mutans at $30 \mathrm{mM}$ concentration of $\mathrm{CaCl}_{2}$ when supplemented carbohydrate was glucose, with sucrose the growth rate was affected in the presence of $\mathrm{CaCl}_{2}$ higher than $30 \mathrm{mM}$ while $\mathrm{MgCl}_{2}$ and $\mathrm{ZnCl}_{2}$ resulted in no changes in growth rate parameter. When fructose was used as a supplementing carbohydrate, the growth rate was affected by $\mathrm{CaCl}_{2}$ higher than $30 \mathrm{mM}$ and $\mathrm{ZnCl}_{2}$ over $1 \mathrm{mM}$; however, $\mathrm{MgCl}_{2}$ showed no effect on this parameter. Interestingly, the growth rate of $S$. mutans clinical isolate $(\mathrm{CI})$ was affected only when glucose and $\mathrm{CaCl}_{2}$ were present; all other combinations showed no significant decrease in this parameter.

The results for growth parameter lag time are shown in Table 1 for both strains. $\mathrm{MgCl}_{2}$ and $\mathrm{ZnCl}_{2}$ were able to prolong the lag time significantly at $30 \mathrm{mM}$ and 1 $\mathrm{mM}$ concentration, respectively; while $\mathrm{CaCl}_{2}$ showed 


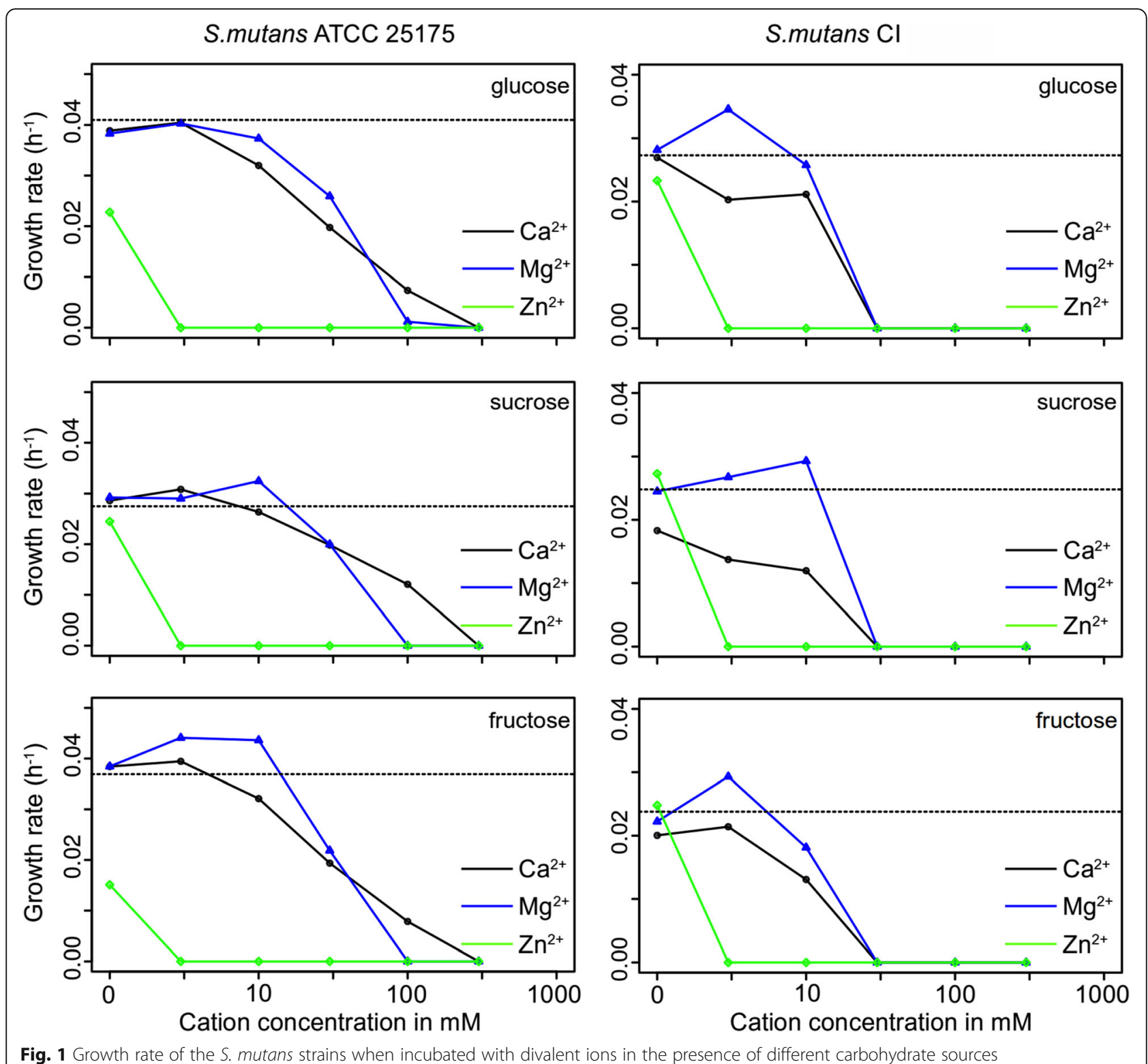

Fig. 1 Growth rate of the S. mutans strains when incubated with divalent ions in the presence of different carbohydrate sources

only minimal effect at $100 \mathrm{mM}$ with glucose and no effect at all with the other carbohydrates in the samples where growth was detected over $48 \mathrm{~h}$. S. mutans CI showed no difference in lag times in all three carbohydrate solutions when incubated with $\mathrm{CaCl}_{2}$, while significant prolongation of the parameter was observed at 10 $\mathrm{mM}$ with $\mathrm{MgCl}_{2}$ and at $1 \mathrm{mM}$ with $\mathrm{ZnCl}_{2}$.

\section{Cariogenic dissolution of hydroxyapatite}

Dissolution of hydroxyapatite was measured in the presence of divalent ions (Fig. 2). There is a dosedependency between the size of the dissolution zone and the concentration of calcium and zinc for all carbohydrates used in this study. Magnesium seems to be promoting the dissolution of hydroxyapatite for both species. However, a significant reduction in hydroxyapatite is first achieved at $100 \mathrm{mM}$ magnesium.

\section{Microscopic analysis of formed biofilm}

The highest concentrations of divalent ions allowing still bacterial survival (and growth based on Fig. 1 and Table 1 ), were selected to check the effect of biofilm formation on hydroxyapatite (HA) disks (Fig. 3, Fig. 4). EPS was visible in all samples that had sucrose as supplemented carbohydrate. Interestingly, while $\mathrm{Ca}^{2+}$ seems to promote the EPS formation by $S$. mutans CI, in S. mutans type strain the least EPS was detected in the presence of this divalent ion. With fructose both strains form a very thin layer of adhered cells and no EPS could be 
Table 1 Lag time of the S. mutans strains when incubated with divalent ions in the presence of different carbohydrate sources

\begin{tabular}{|c|c|c|c|c|c|c|c|c|}
\hline \multirow[t]{2}{*}{ Carbohydrate } & \multirow{2}{*}{$\begin{array}{l}\text { Added } \\
\text { agent }\end{array}$} & \multicolumn{7}{|l|}{ lag time $(\mathrm{h})$} \\
\hline & & $0 \mathrm{mM}$ & $1 \mathrm{mM}$ & $3 \mathrm{mM}$ & $10 \mathrm{mM}$ & $30 \mathrm{mM}$ & $100 \mathrm{mM}$ & $200 \mathrm{mM}$ \\
\hline \multicolumn{9}{|c|}{ S. mutans ATCC 25175} \\
\hline Glucose & $\mathrm{CaCl}_{2}$ & $9.58 \pm 0.14$ & $9.69 \pm 0.20$ & $9.77 \pm 0.14$ & $9.98 \pm 0.09$ & $9.70 \pm 0.47$ & $11.65 \pm 0.63$ & ND \\
\hline Sucrose & & $7.91 \pm 0.79$ & $7.79 \pm 1.14$ & $7.94 \pm 0.81$ & $8.11 \pm 0.45$ & $9.26 \pm 0.88$ & $9.77 \pm 0.27$ & ND \\
\hline Fructose & & $6.90 \pm 0.56$ & $7.61 \pm 0.53$ & $7.50 \pm 0.49$ & $7.30 \pm 0.49$ & $8.67 \pm 0.20$ & $8.39 \pm 0.24$ & ND \\
\hline Glucose & $\mathrm{MgCl}_{2}$ & $9.58 \pm 0.14$ & $9.68 \pm 0.19$ & $9.56 \pm 0.04$ & $10.30 \pm 0.49$ & $21.92 \pm 0.97$ & $24.11 \pm 0.00$ & ND \\
\hline Sucrose & & $7.91 \pm 0.79$ & $7.94 \pm 0.96$ & $8.09 \pm 0.92$ & $8.91 \pm 1.00$ & $23.71 \pm 2.62$ & ND & ND \\
\hline Fructose & & $6.90 \pm 0.56$ & $7.28 \pm 0.64$ & $7.56 \pm 0.59$ & $8.56 \pm 0.35$ & $16.40 \pm 0.95$ & ND & ND \\
\hline Glucose & $\mathrm{ZnCl}_{2}$ & $9.58 \pm 0.14$ & $17.82 \pm 2.46$ & ND & ND & ND & ND & ND \\
\hline Sucrose & & $7.91 \pm 0.79$ & $13.86 \pm 1.17$ & ND & ND & ND & ND & ND \\
\hline Fructose & & $6.90 \pm 0.56$ & $17.28 \pm 2.01$ & ND & ND & ND & ND & ND \\
\hline \multicolumn{9}{|l|}{ S. mutans $\mathrm{Cl}$} \\
\hline Glucose & $\mathrm{CaCl}_{2}$ & $12.10 \pm 0.44$ & $11.76 \pm 0.96$ & $12.84 \pm 0.56$ & $11.83 \pm 0.46$ & ND & ND & ND \\
\hline Sucrose & & $10.11 \pm 0.73$ & $10.83 \pm 0.71$ & $10.52 \pm 0.85$ & $10.89 \pm 0.44$ & ND & ND & ND \\
\hline Fructose & & $12.83 \pm 1.37$ & $13.02 \pm 1.82$ & $12.61 \pm 0.70$ & $13.47 \pm 1.26$ & ND & ND & ND \\
\hline Glucose & $\mathrm{MgCl}_{2}$ & $12.10 \pm 0.44$ & $11.86 \pm 0.60$ & $12.14 \pm 0.50$ & $16.96 \pm 1.66$ & ND & ND & ND \\
\hline Sucrose & & $10.11 \pm 0.73$ & $10.27 \pm 0.57$ & $9.98 \pm 0.62$ & $15.75 \pm 1.25$ & ND & ND & ND \\
\hline Fructose & & $12.83 \pm 1.37$ & $12.81 \pm 1.77$ & $12.94 \pm 1.33$ & $21.38 \pm 3.94$ & ND & ND & ND \\
\hline Glucose & $\mathrm{ZnCl}_{2}$ & $12.10 \pm 0.44$ & $15.76 \pm 0.92$ & ND & ND & ND & ND & ND \\
\hline Sucrose & & $10.11 \pm 0.73$ & $17.91 \pm 0.64$ & ND & ND & ND & ND & ND \\
\hline Fructose & & $12.83 \pm 1.37$ & $16.36 \pm 1.80$ & ND & ND & ND & ND & ND \\
\hline
\end{tabular}

observed. Adding glucose to the solution seems to have no effect in promoting growth, in case of S. mutans CI almost no adherent cells were detected in the presence of $\mathrm{Zn}^{2+}$, while adhesion seems to be more inhibited by $\mathrm{Ca}^{2+}$ and $\mathrm{Mg}^{2+}$ for $S$. mutans type strain.

\section{Analysis of the binding of the divalent ions to EPS}

Yield of EPS was determined by sulphuric acid assay and the results for glucose, sucrose, and fructose in case of $S$. mutans type strain were $0.74 \mathrm{mg} / \mathrm{mL}, 1.22$ $\mathrm{mg} / \mathrm{mL}$, and $0.70 \mathrm{mg} / \mathrm{mL}$, respectively. For $S$. mutans CI, similar results were measured: $0.73 \mathrm{mg} / \mathrm{mL}, 1.61$ $\mathrm{mg} / \mathrm{mL}$, and $0.83 \mathrm{mg} / \mathrm{mL}$ respectively.

The binding affinity of EPS to the tested divalent ions seems to be strain-related for calcium and magnesium, while the affinity to zinc is comparable between those two strains (Table 2). The EPS of S. mutans CI has a higher binding affinity towards calcium and magnesium than the type strain and the results are in the same order of magnitude than the ions' affinity to dextran. Other parameters detected by isothermal titration calorimetry (ITC) show comparable results between the strains. However, one has to keep in mind that such result can only be an estimate as the complexity of the many binding sites of EPS is not reflected by the single step equilibrium model.

Additional experiments were conducted where EPS was saturated by magnesium and thereafter the titration was conducted with calcium. No calcium could be bound for both strains as magnesium had saturated all the binding sites.

\section{Discussion}

The interactions between the hard tissues of the teeth and the environment of the oral cavity depend on salivary proteins and enzymes among others but also on dissolved ions [32, 33]. Calcium dissolved in saliva is known to influence the process of de- and remineralization of the tooth enamel which in combination with cariogenic microbes can lead to caries and to a reduction of the general health condition $[34,35]$. Therefore, it is important to understand the interactions between microorganisms, components of saliva, and the tooth mineral surface, to ensure a good oral health. Thus, this study investigates the effect of divalent cations on the formation of cariogenic biofilm in order to find the importance of these ions and how to prevent EPS and biofilms formation in different conditions. In order to investigate the effect of virulence we used a type 


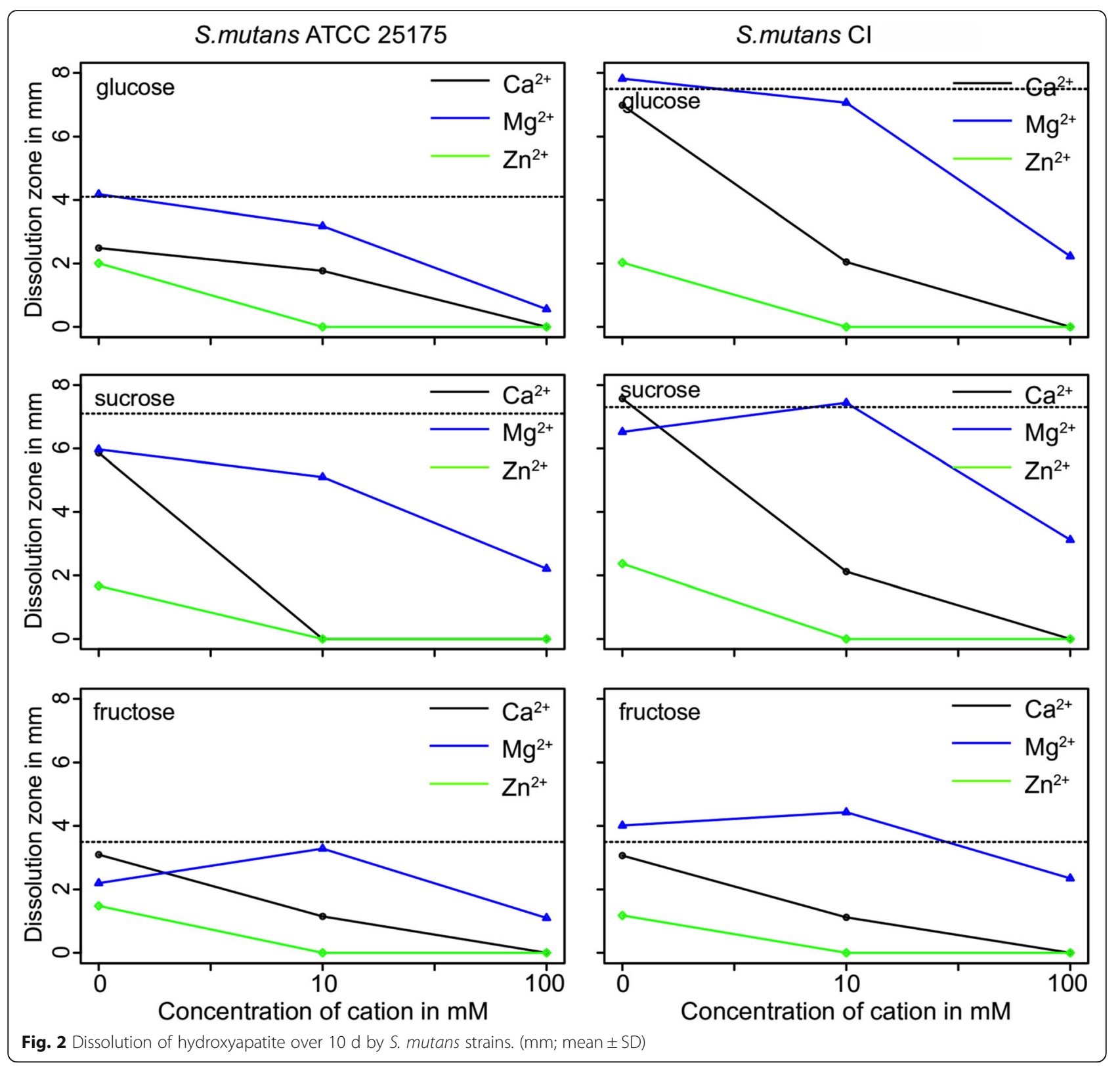

strain but also a clinical isolate, that has been studied earlier as the structure and composition of EPS is affected by the characteristics acquired by the strain to survive in certain environments. Thus, here a type strain was used to provide as much reproducibility as possible as the strain is well-characterized and in comparison, a clinical isolate that has mutated already to survive in highly cariogenic lesions with low $\mathrm{pH}$ [8].

The exoenzymes of $S$. mutans are capable of forming EPS in attendance of glucose, fructose, and sucrose, a disaccharide of glucose and fructose $[8,36]$. As the main components of the matrix are EPS, they are found to be a substantial virulence factor associated with dental caries with some variances in their functional groups due to differences in the carbohydrates that were fermented [36]. However, previous studies have mostly used EPS formed in the presence of sucrose; thus, here also the aspect how carbohydrate influence the EPS abundance to divalent ions was assessed. Due to the primary binding sites formed by EPS, various constituents of saliva are able to affect the microbial adhesion to the dental plaque by influencing the electrostatic interactions $[8,37]$. Therefore, the selective adhesion and accumulation of pathogenic streptococci, but also the binding of biologically important cations such as $\mathrm{Ca}^{2+}, \mathrm{Mg}^{2+}$, $\mathrm{Fe}^{2+/ 3+}$ and $\mathrm{Zn}^{2+}$, can take place. EPS have numerous negatively charged functional groups (carboxyl, 

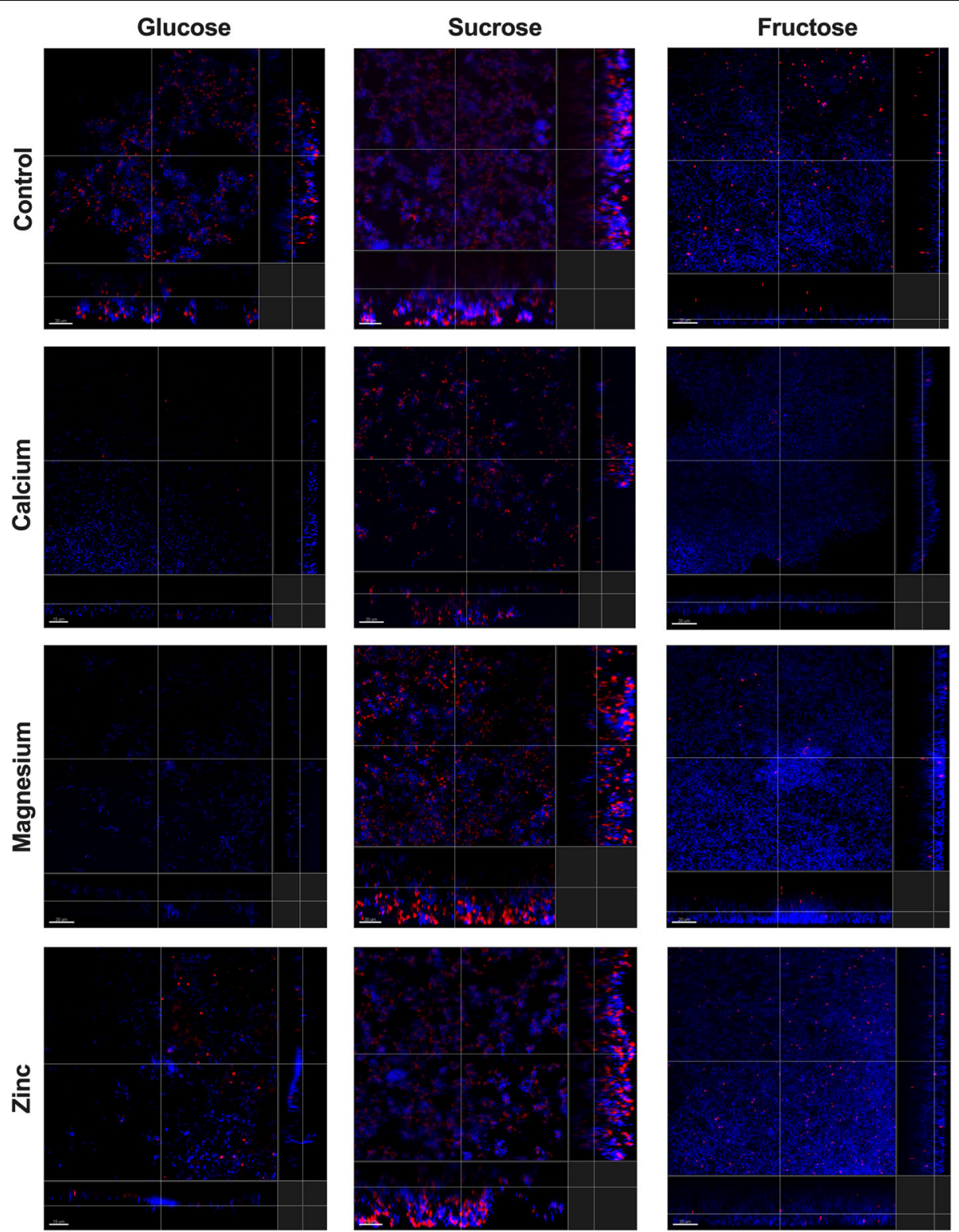

Fig. 3 Formation of S. mutans ATCC 25175 biofilms on hydroxyapatite disks in the presence of divalent ions

phosphate and amine groups) $[8,38]$ that are capable to interact with positive charged cations, thereby also with the three divalent ions used in this study $\left(\mathrm{Mg}^{2+}\right.$, $\mathrm{Zn}^{2+}$ and $\left.\mathrm{Ca}^{2+}\right)[19,39]$. Thus, if several of the negative functional groups were bound by these cations, the structure and function of the entire biofilm could be changed and consequently reduce (or in worst case possibly enhance) the development of caries.

Calcium is predominantly known as an important regulatory ion for almost all of the pro- and eukaryotic cells [40]. Along with other ions, calcium plays a specific role in the cariogenic biofilm formation of caries-related species. Demineralization of tooth surface always results in a calcium release and an increase of the calcium concentration in the biofilm and its close surroundings, which might have a negative effect on the microbes $[8$, 41]. S. mutans strains used in this study show the highest tolerance towards calcium of the three ions tested. Both of the growth parameters lag time (Table 1) and growth rate (Fig. 1) of the strains showed no differences to control condition up to $100 \mathrm{mM}$ concentration; meaning the cariogenic strains have a natural tolerance to higher concentration of calcium in the surroundings. Although excessive levels of calcium did not impair the growth parameters, it also did not have a positive effect on biofilm formation (Fig. 3, Fig. 4) or its binding affinity to EPS (Table 2). While in many aspects' calcium revealed similar action to magnesium in this study (Table 

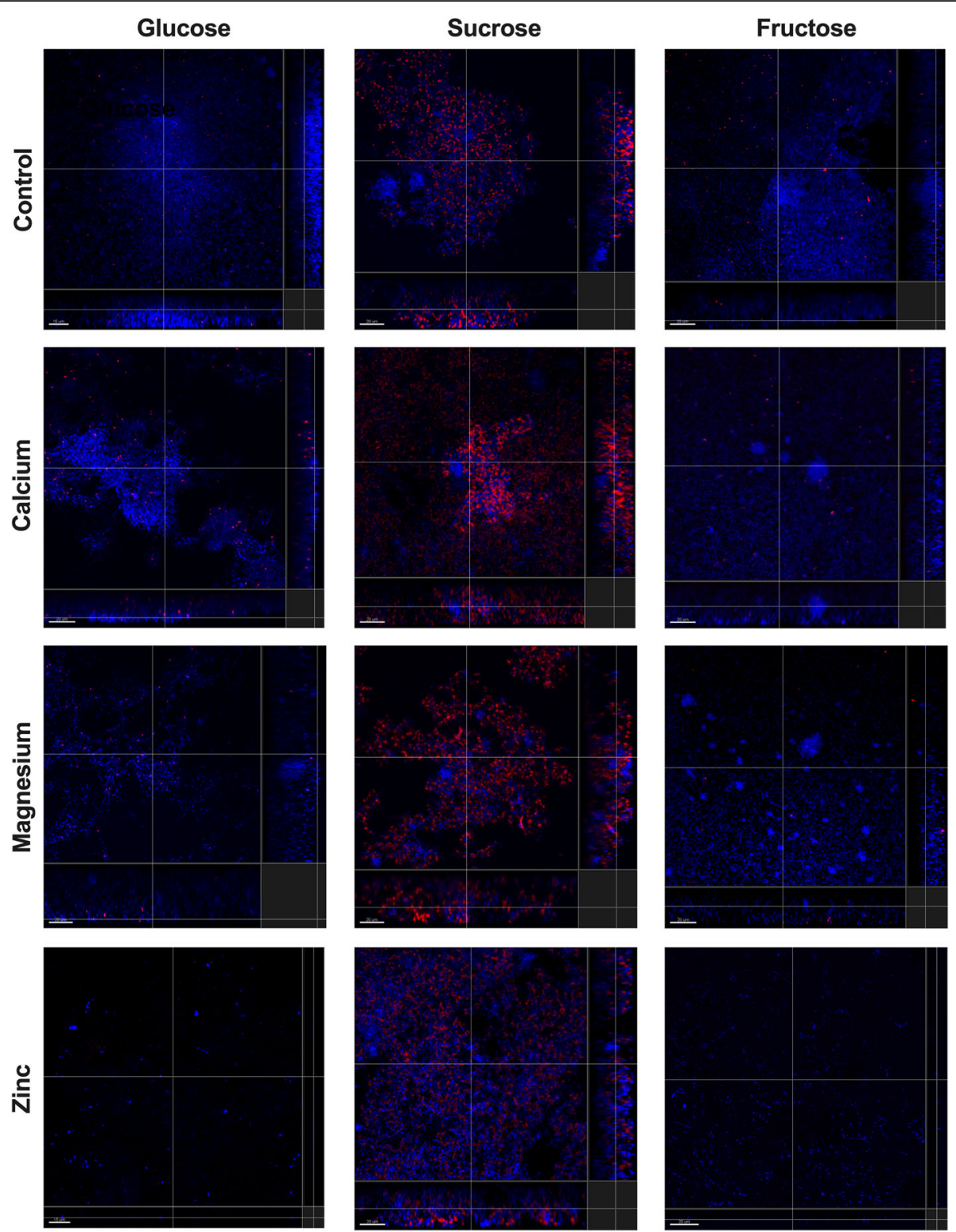

Fig. 4 Formation of S. mutans $\mathrm{Cl}$ biofilms on hydroxyapatite disks in the presence of divalent ions

2), it is less prone to promote the growth of biofilm (Fig. 3, Fig. 4) and the cariogenic effects of mutans steptococci (Fig. 2) as magnesium seems to be doing.

Magnesium is capable of altering the cell structure, thereby preventing bacterial adhesion, which results in a disruption of the development of biofilm [42]. Interestingly, here no such effect was seen. Magnesium promoted dissolution of calcium from hydroxyapatite (Fig. 2) as well as the formation of biofilms (Fig. 3, Fig. 4). That is interesting as no such effect is seen in vivo. That; however, might be contributed to the fact that the average $\mathrm{Mg}^{2+}$ concentration in dental plaque is lower than that of $\mathrm{Ca}^{2+}$. Moreover, $\mathrm{Mg}^{2+}$ acts as a competitive inhibitor and can reduce through ionic interactions $\mathrm{Ca}^{2+}$ binding by approximately $15 \%$ [43].
In this study it could be shown that $\mathrm{Mg}^{2+}$-saturated EPS could not bind any longer any $\mathrm{Ca}^{2+}$ ions; this might be due to the small differences between magnesium and calcium binding affinity suggesting that magnesium could not replace the calcium at least at low concentrations. Consequently, a production of a $\mathrm{Mg}^{2+}$-saturated environment can be counterproductive as mutans streptococci are able to dissolve more $\mathrm{Ca}^{2+}$ from the tooth surface in the presence of magnesium, therefore releasing excessive amounts of $\mathrm{Ca}^{2+}$ in the environment and leading to the progression of the disease $[40,41,43]$. Thus, as magnesium seems to promote dissolution at high concentrations it supports the idea of self-regulation, when more $\mathrm{Ca}^{2+}$ is released, more calcium is bound to the biofilm strengthening its structure 
Table 2 Parameters assessed by isothermal titration calorimetry (ITC) for EPS extracted from S. mutans strains using different carbohydrate source

\begin{tabular}{|c|c|c|c|c|c|}
\hline \multirow[t]{2}{*}{ Carbohydrate } & \multirow[t]{2}{*}{ Titration agent } & \multicolumn{4}{|c|}{ S. mutans ATCC 25175} \\
\hline & & k & $\Delta \mathrm{H}_{1}(\mathrm{~kJ} / \mathrm{mol})$ & $\Delta \mathrm{G}_{1}(\mathrm{~kJ} / \mathrm{mol})$ & $\Delta \mathrm{S}_{1}(\mathrm{~J} /(\mathrm{k} \times \mathrm{mol}))$ \\
\hline Glucose & \multirow[t]{3}{*}{$\mathrm{CaCl}_{2}$} & $3.7 \times 10^{3}\left( \pm 5.0 \times 10^{2}\right)$ & $-58.5( \pm 3.6)$ & -20.3 & -127.9 \\
\hline Sucrose & & $3.1 \times 10^{3}\left( \pm 7.9 \times 10^{2}\right)$ & $-58( \pm 14)$ & -19.9 & -126.4 \\
\hline Fructose & & $9.2 \times 10^{3}\left( \pm 1.7 \times 10^{3}\right)$ & $-25.6( \pm 1.2)$ & -22.6 & -9.9 \\
\hline Glucose & \multirow[t]{3}{*}{$\mathrm{MgCl}_{2}$} & $7.9 \times 10^{3}\left( \pm 1.5 \times 10^{3}\right)$ & $-43.6( \pm 2.6)$ & -22.2 & -71.8 \\
\hline Sucrose & & $5.3 \times 10^{3}\left( \pm 2.3 \times 10^{3}\right)$ & $7.8( \pm 1.4)$ & -21.5 & 97.1 \\
\hline Fructose & & $1.9 \times 10^{3}\left( \pm 1.3 \times 10^{3}\right)$ & $22( \pm 40)$ & -19.0 & 137.6 \\
\hline Glucose & \multirow[t]{3}{*}{$\mathrm{ZnCl}_{2}$} & $1.4 \times 10^{4}\left( \pm 0.72 \times 10^{4}\right)$ & $16( \pm 2.8)$ & -23.9 & 133.2 \\
\hline Sucrose & & $3.9 \times 10^{3}\left( \pm 0.71 \times 10^{3}\right)$ & $17( \pm 12)$ & -20.7 & 220.9 \\
\hline Fructose & & $3.6 \times 10^{3}\left( \pm 0.66 \times 10^{3}\right)$ & $31( \pm 5.6)$ & -20.5 & 172.1 \\
\hline \multirow[t]{2}{*}{ Carbohydrate } & \multirow[t]{2}{*}{ Titration agent } & \multicolumn{4}{|l|}{ S. mutans $\mathrm{Cl}$} \\
\hline & & k & $\Delta \mathrm{H}_{1}(\mathrm{~kJ} / \mathrm{mol})$ & $\Delta \mathrm{G}_{1}(\mathrm{~kJ} / \mathrm{mol})$ & $\Delta \mathrm{S}_{1}(\mathrm{~J} /(\mathrm{k} \times \mathrm{mol}))$ \\
\hline Glucose & \multirow[t]{3}{*}{$\mathrm{CaCl}_{2}$} & $1.1 \times 10^{4}\left( \pm 3.2 \times 10^{3}\right)$ & $-29.0( \pm 2.0)$ & -23.2 & -19.6 \\
\hline Sucrose & & $4.9 \times 10^{4}\left( \pm 2.0 \times 10^{3}\right)$ & $4.78( \pm 0.20)$ & -26.8 & 105.9 \\
\hline Fructose & & $1.2 \times 10^{4}\left( \pm 2.2 \times 10^{3}\right)$ & $-6.0( \pm 0.25)$ & -24.2 & 58.6 \\
\hline Glucose & \multirow[t]{3}{*}{$\mathrm{MgCl}_{2}$} & $1.4 \times 10^{4}\left( \pm 0.44 \times 10^{4}\right)$ & $9.5( \pm 0.73)$ & -23.9 & 110.9 \\
\hline Sucrose & & $1.5 \times 10^{4}\left( \pm 0.91 \times 10^{4}\right)$ & $4.4( \pm 0.65)$ & -24.1 & 94.9 \\
\hline Fructose & & $1.7 \times 10^{4}\left( \pm 1.4 \times 10^{4}\right)$ & $6.2( \pm 1.5)$ & -24.4 & 101.7 \\
\hline Glucose & \multirow[t]{3}{*}{$\mathrm{ZnCl}_{2}$} & $4.8 \times 10^{3}\left( \pm 0.79 \times 10^{3}\right)$ & $42( \pm 6.3)$ & -21.2 & 209.2 \\
\hline Sucrose & & $4.2 \times 10^{3}\left( \pm 1.1 \times 10^{3}\right)$ & $34( \pm 4.8)$ & -20.9 & 182.8 \\
\hline \multirow[t]{6}{*}{ Fructose } & & $4.8 \times 10^{3}\left( \pm 0.79 \times 10^{3}\right)$ & $42( \pm 6.3)$ & -21.2 & 209.2 \\
\hline & \multirow[t]{2}{*}{ Titration agent } & Dextran & & & \\
\hline & & k & $\Delta \mathrm{H}_{1}(\mathrm{~kJ} / \mathrm{mol})$ & $\Delta \mathrm{G}_{1}(\mathrm{~kJ} / \mathrm{mol})$ & $\Delta \mathrm{S}_{1}(\mathrm{~J} /(\mathrm{k} \times \mathrm{mol}))$ \\
\hline & $\mathrm{CaCl}_{2}$ & $2.6 \times 10^{4}\left( \pm 7.3 \times 10^{3}\right)$ & $5.60( \pm 0.21)$ & -25.2 & 102.2 \\
\hline & $\mathrm{MgCl}_{2}$ & $3.2 \times 10^{4}\left( \pm 8.6 \times 10^{3}\right)$ & $8.29( \pm 0.28)$ & -25.9 & 113.7 \\
\hline & $\mathrm{ZnCl}_{2}$ & $2.1 \times 10^{4}\left( \pm 5.2 \times 10^{3}\right)$ & $5.99( \pm 0.25)$ & -24.7 & 102.9 \\
\hline
\end{tabular}

and less is left for remineralization [8]. Therefore, magnesium might not be the best agent to control the calcium flow in cariogenic biofilms.

Also zinc is a trace element with antibacterial properties and is present in the whole structure of the teeth [29], with the highest concentrations found in the outermost layer. Zinc is easily absorbed by the hydroxyapatite and can reach a position on the apatite crystal, making it resistant to acid dissolution. This could explain why the outer enamel layer is more resistant against caries than the subsurface [28] and why already a low concentration of $\mathrm{Zn}^{2+}$ inhibited bacterial adhesion (Fig. 3, Fig. 4), and had a strong antibacterial effect on mutans streptococcal growth (Fig. 1, Table 1) as well as on calcium dissolution (Fig. 2); leading to less biofilm and less EPS, ultimately resulting in a lesser cariogenic effect caused by mutans streptococci. Additionally, the titration data show that $\mathrm{Zn}^{2+}$ was having almost always the lowest affinity to all EPS used in this study (Table 2); thus, the unbound zinc could also still remain in the surrounding environment and keep its antimicrobial properties. Zinc binds the fructosyl site in the catalytic domain through an enzymatic action, leading to the inactivation of glucosyltransferases. Therefore, the glucan synthesis can be inhibited and thus, biofilm production reduced [30], which was also seen in Fig. 3 and Fig. 4. The effect of the reduced dissolution of hydroxyapatite (Fig. 2) has been shown earlier where in vitro studies have demonstrated the inhibitory effect of $\mathrm{Zn}^{2+}$ on the demineralization of hard tooth structure [44]. Of course, it must be mentioned that calcium found in the cariogenic cavity desorbs $\mathrm{Zn}^{2+}$ easily from hydroxyapatite and can therefore lead to alternate interactions that are not always easy to detect [29].

\section{Conclusions}

The study illustrates how three divalent ions that are present in the upper layers of tooth surface are able to regulate the growth of mutans streptococci on the 
surface as well as when released in the surface or added externally to the surroundings affect the formation of cariogenic biofilms and their ability to dissolve tooth surface. There seems to be a fine balance between these ions that needs to be maintained as excessive concentrations of one or another destroy the healthy relationship between the three.

\section{Materials and methods}

\section{Effect of divalent ions on the growth of mutans} streptococci

Ten microliter stock solution of $S$. mutans (ATCC 25175) and S. mutans clinical isolate (CI [8];) were streaked on Columbia blood agar plates $\left(\mathrm{BBL}^{\mathrm{TM}}\right.$, Becton Dickinson, Basel, Switzerland; supplemented with 50 $\mathrm{mL} / \mathrm{L}$ of human blood, $0.5 \mathrm{mg} / \mathrm{L}$ of menadione, and 5 $\mathrm{mg} / \mathrm{L}$ of hemin) and incubated aerobically at least $72 \mathrm{~h}$ at $37^{\circ} \mathrm{C}$.

Todd Hewitt medium was supplemented with either glucose (20 g/L; Sigma-Aldrich, Buchs, Switzerland), sucrose (20 g/L; Sigma-Aldrich, Buchs, Switzerland), or fructose (20 g/L; Sigma-Aldrich, Buchs, Switzerland) and colonies were resuspended to match McFarland 0.5 standard. Different concentrations $(1,3,10,30,100$ and $200 \mathrm{mM}$ ) of $\mathrm{CaCl}_{2}, \mathrm{MgCl}_{2}$, and $\mathrm{ZnCl}_{2}$ were added to the bacterial solution. A 48-well-plate was used to measure growth of bacteria in different solutions; for this $500 \mu \mathrm{L}$ of prepared solutions was pipetted into the wells in duplicate and the plate was incubated at $37^{\circ} \mathrm{C}$ for $48 \mathrm{~h}$, aerobically in a plate reader (HTX Synergy, Biotek, Switzerland). Optical density $\left(\mathrm{OD}_{600} \mathrm{~nm}\right)$ of the cultures was measured with intervals of $1 \mathrm{~h}$, prior to each measurement the plate went through a short orbital shaking for $20 \mathrm{~s}$ with $500 \mathrm{rpm}$. All experiments were repeated three times in triplicates $(n=9)$.

The bacterial suspension with no divalent ions added served as a growth control and medium with no bacteria added was used as a blank measurement. All results were obtained as blank corrected growth curves over time. The data were analyzed using R-software and grofit package [45].

\section{Microscopic analysis of biofilm formations}

The highest concentrations of divalent ions allowing bacterial growth were selected for biofilm formation on hydroxyapatite (HA) disks (5 mm in diameter; HiMed Inc., New York, USA). Bacterial suspension was prepared as described earlier and was supplemented with either $100 \mathrm{mM} \mathrm{CaCl}_{2}$ and $30 \mathrm{mM}$ (glucose) or $10 \mathrm{mM} \mathrm{MgCl} 2$ (sucrose and fructose) and $1 \mathrm{mM} \mathrm{ZnCl}_{2}$ for S. mutans ATCC25175; and $10 \mathrm{mM} \mathrm{CaCl} 2$ and $10 \mathrm{mM} \mathrm{MgCl}_{2}$ and $1 \mathrm{mM} \mathrm{ZnCl}_{2}$ for S. mutans CI. Additionally, the samples used for confocal laser scanning microscopy (CLSM) later on were also incubated with $1 \mathrm{mM}$ Alexa 647- dextrane-conjugate (Dextran, Alexa Fluor ${ }^{\mathrm{TM}}$ 647; 10,000 MW; Invitrogen ${ }^{\mathrm{Tm}}$, Thermo Fisher, Reinach, Switzerland) in order to visualize the EPS formed in biofilms. Prior to biofilm formation, the disks were coated with $500 \mu \mathrm{L}$ serum/saliva mixture $(1: 10)$ for $15 \mathrm{~min}$ at room temperature (RT) [34]. Thereafter, the disks were placed in bacterial suspension and incubated at $37^{\circ} \mathrm{C}$ for $24 \mathrm{~h}$. After that the samples were shortly dipped in $0.9 \% \mathrm{NaCl}$ and prepared for CLSM.

The samples were placed in $500 \mu \mathrm{L} 300 \mathrm{nM}$ DAPI solution for $3 \mathrm{~min}$ to visualize the cells in biofilms, at RT in darkness. Thereafter, the samples were rinsed in $0.9 \%$ $\mathrm{NaCl}$ and placed upside down in Mowiol solution. All samples were imaged with Leica SP8 microscope (Leica SP8, Heerbrugg, Switzerland) using 63x (1.4x) oil immersion objective with Z-stack step of $0.3 \mu \mathrm{m}$. Three disks with biofilms were analyzed per condition $(n=3)$.

\section{Cariogenic dissolution of hydroxyapatite}

Pikovskaya's agar (5 g of HA powder, $0.5 \mathrm{~g}$ of $\left(\mathrm{NH}_{4}\right)_{2} \mathrm{SO}_{4}$, $0.2 \mathrm{~g}$ of $\mathrm{NaCl}, 0.1 \mathrm{~g}$ of $\mathrm{MgSO}_{4} * 7 \mathrm{H}_{2} \mathrm{O}, 0.2 \mathrm{~g}$ of $\mathrm{KCl}, 0.5$ $\mathrm{g}$ of yeast extract, $0.002 \mathrm{~g}$ of $\mathrm{MnSO}_{4} * \mathrm{H}_{2} \mathrm{O}, 0.002 \mathrm{~g}$ of $\mathrm{FeSO}_{4} * 7 \mathrm{H}_{2} \mathrm{O}$, and $15 \mathrm{~g}$ of agar, all dissolved it in $1 \mathrm{~L}$ of $\mathrm{H}_{2} \mathrm{O}$ ) was used to measure the impact of different concentrations of $(1,10$, and $100 \mathrm{mM})$ of $\mathrm{CaCl}_{2}, \mathrm{MgCl}_{2}$, and $\mathrm{ZnCl}_{2}$ of hydroxyapatite dissolution by $S$. mutans strains. Additionally, the medium was supplemented with either glucose (20 g/L; Sigma-Aldrich, Buchs, Switzerland), sucrose (20 g/L; Sigma-Aldrich, Buchs, Switzerland), or fructose (20 g/L; Sigma-Aldrich, Buchs, Switzerland).

A colony of $S$. mutans was inserted in the middle of the Pikovskaya's agar and the plates were incubated aerobically for 10 days at $37^{\circ} \mathrm{C}$ and thereafter, the dissolution zones were measured $(n=10)$.

\section{EPS extraction of S. mutans cultures}

Ten microliter of the stock solutions (S. mutans ATCC 25175 and $S$. mutans clinical isolate), stored at $-80^{\circ} \mathrm{C}$, were inoculated into $5 \mathrm{~mL}$ Luria broth $\left(\mathrm{BBL}^{\mathrm{Tm}}\right.$, Becton Dickinson, Basel, Switzerland) and incubated aerobically for $20 \pm 2 \mathrm{~h}$, at $37^{\circ} \mathrm{C}$. Thereafter, $1 \mathrm{~mL}$ of the preculture of $S$. mutans clinical isolate and $4 \mathrm{~mL}$ of the preculture of S. mutans ATCC 25175 were inoculated into $1 \mathrm{~L}$ of $50 \%$ Luria broth supplemented with glucose, sucrose, or fructose (end concentration $20 \mathrm{~g} / \mathrm{L}$ ). Previously, the turbidity of the preculture, and thus the approximate number of bacteria, was measured with the Eppendorf BioSpectometer $\left(\mathrm{OD}_{600}\right)$. The culture was incubated for $48 \mathrm{~h}$ under aerobic conditions $37^{\circ} \mathrm{C}$ on a shaker set to $240 \mathrm{rpm}$.

The grown cultures were processed through glass-fiber filters (Millipore ${ }^{\circledast}$ Type 2 filters, retention 1,0 $\mu \mathrm{m}$; SigmaAldrich, Buchs, Switzerland) and $0.22 \mu \mathrm{m}$ filters (Millipore StericupTM filter units PVDF membrane (Durapore); 
Sigma-Aldrich, Buchs, Switzerland). In order to obtain a precipitate of EPS, cold ethanol (Sigma-Aldrich, Buchs, Switzerland) had to be added in the ratio 2:1 to the solution. The precipitation was carried out for at least $12 \mathrm{~h}$ in a cold room at $4{ }^{\circ} \mathrm{C}$.

The solution with the precipitated EPS was centrifuged the next day for $10 \mathrm{~min}$ at $3000 \mathrm{rpm}$ (Sigma 4-16KS, Adolf Kühner AG, Birsfelden, Switzerland) at $4{ }^{\circ} \mathrm{C}$. The liquid was discarded, and the recovered EPS was redissolved in ethanol and placed in dialysis bags (cellulose membrane, molecular weight cut-off 14'000 Da; SigmaAldrich, Buchs, Switzerland) to eliminate small molecular weight organic compounds. The dialysis was repeated two consecutive times against 31 of $1 \mathrm{mM}$ EDTA (Sigma-Aldrich, Buchs, Switzerland), followed by three dialysis against ultrapure water at $4{ }^{\circ} \mathrm{C}$. Each of these steps lasted at least overnight. The dialyzed EPS was stored at $4{ }^{\circ} \mathrm{C}$.

The concentration of EPS was measured by the phenol - sulphuric acid assay [46]. Briefly, $50 \mu \mathrm{L}$ of the EPS was mixed with $500 \mu \mathrm{L}$ deionized water, to this $25 \mu \mathrm{L}$ of phenol was added and stirred properly. Thereafter, $2 \mathrm{~mL}$ of concentrated sulphuric acid was added as fast as possible. After $20 \mathrm{~min}$ the absorbance was measured at 490 $\mathrm{nm}$ (Eppendorf BioSpectrometer; Vaudaux-Eppendorf AG, Schönenbuch, Switzerland). In order to relate the values to concentrations, standard curve of $0.08 \%$ xanthan was also measured $(0 \mu \mathrm{L}, 20 \mu \mathrm{L}, 40 \mu \mathrm{L}, 60 \mu \mathrm{L} 80 \mu \mathrm{L}$ and $100 \mu \mathrm{L}), n=5$.

\section{Analysis of the binding of the divalent ions to EPS}

The binding of $\mathrm{ZnCl}_{2}, \mathrm{MgCl}_{2}$ and $\mathrm{CaCl}_{2}$ to EPS was analyzed by isothermal titration calorimetry (ITC). For every experiment the ITC ampoule was filled with $2.7 \mathrm{~mL}$ of EPS solution freshly dialyzed against the used buffer (see below) and the syringe with $300 \mu \mathrm{L}$ divalent cation solution prepared in the same buffer. The ampoule with the EPS and the syringe with the divalent ions were placed in the TAM III ITC system (Waters / TA instruments, Delaware, USA), the titration parameters were defined as follows: 17 injections, each $15 \mu \mathrm{L}$ over $15 \mathrm{~s}$ with an interval of $45 \mathrm{~min}$. Blank titrations were made with the buffer used. Titration were performed using $30 \mathrm{mM}$ Tris pH 8.5 as buffer for $\mathrm{CaCl}_{2}$ and $\mathrm{MgCl}_{2}$. For $\mathrm{ZnCl}_{2}$ deionized water was used due to precipitation of $\mathrm{Zn}$ oxydes or hydroxydes. Care was taken to adjust the $\mathrm{pH}$ of the water to the same value as EPS samples used. In addition to EPS samples, dextran was used as a commercially available polysaccharide as a reference compound. Binding parameters and affinity were calculated using the TA instrument embedded software (TAM assistant) and assuming a single equilibrium step. All experiments were repeated twice $(n=2)$.

\section{Statistical analysis}

In order to identify differences between the control group not exposed to divalent ions and the other groups, data were analyzed by Student's t-test with significance level set to $p<0.05$ using GraphPad Prism 8.0. Normality test was performed in order to verify that the distributional assumptions were met for the t-test using the Shapiro-Wilk test for small sample size.

\section{Abbreviations \\ DAPI: 4',6-Diamidine-2'-phenylindole dihydrochloride; Cl: Clinical isolate; CLSM: Confocal laser scanning microscopy; EPS: Exopolysaccharides; HA: Hydroxyapatite; ITC: Isothermal titration calorimetry; OD: Optical density; RT: Room temperature}

\section{Acknowledgements}

We would like to thank the team of Imaging Core Facility of the University of Basel for helping to optimize the microscopy experiments. OB wishes to thank the Merian Iselin Stiftung.

\section{Authors' contributions}

$M A F, T W$, and $O B$ designed the study, supervised and responsible for results analysis and interpretation of the data. ELS and JRM performed the all the experiments and wrote the draft for the manuscript. The authors read, amended and approved the manuscript.

\section{Funding}

The work was not supported by any external funding source.

\section{Availability of data and materials}

The datasets used and/or analysed during the current study are available from the corresponding author on reasonable request.

Ethics approval and consent to participate

Not applicable.

\section{Consent for publication}

Not applicable.

\section{Competing interests}

The authors declare that they have no competing interests.

\section{Author details}

${ }^{1}$ Department for Oral Health \& Medicine, University Center for Dental Medicine (UZB), University of Basel, Mattenstrasse 40, 4058 Basel, Switzerland. ${ }^{2}$ Center of Biomechanics and Biocalorimetry, c/o Department of Biomedical Engineering (DBE), University of Basel, Gewerbestrasse 14, 4123 Allschwil, Switzerland. 'Department Research, University Center for Dental Medicine (UZB), University of Basel, Mattenstrasse 40, 4058 Basel, Switzerland.

Received: 6 July 2020 Accepted: 10 September 2020

Published online: 16 September 2020

\section{References}

1. Lee Y. Diagnosis and prevention strategies for dental caries. J Lifestyle Med. 2013;3(2):107-9.

2. Struzycka I. The oral microbiome in dental caries. Pol J Microbiol. 2014;63(2): 127-35.

3. Wagner $Y$, Heinrich-Weltzien R. Risk factors for dental problems: recommendations for oral health in infancy. Early Hum Dev. 2017;114:16-21.

4. Fejerskov O, Kidd E. Dental caries: the disease and its Cliical management. 2nd ed. Oxford, UK: AMes. lowa: Blackwell Munksgaard; 2008.

5. Amaechi BT. Karieskontrolle durch Beeinflussung der Ernährung. In: MeyerLückel H, Paris S, Exstrand KH, editors. Karies. Teil 1: Karies - Wissenschaft. Stuttgart, New York, Delhi, Rio: Thieme Verlagsgruppe; 2012. p. 177-8.

6. Scheinin A, Makinen KK, Ylitalo K. Turku sugar studies. V. Final report on the effect of sucrose, fructose and xylitol diets on the caries incidence in man. Acta Odontol Scand. 1976:34(4):179-216.

7. Zero DT. Sugars - the arch criminal? Caries Res. 2004;38(3):277-85. 
8. Astasov-Frauenhoffer M, Varenganayil MM, Decho AW, Waltimo T, Braissant O. Exopolysaccharides regulate calcium flow in cariogenic biofilms. PLoS One. 2017;12(10):e0186256

9. Paes Leme AF, Koo H, Bellato CM, Bedi G, Cury JA. The role of sucrose in cariogenic dental biofilm formation--new insight. J Dent Res. 2006;85(10): 878-87.

10. Chenicheri S, Usha R, Ramachandran R, Thomas V, Wood A. Insight into Oral biofilm: primary, secondary and residual caries and Phyto-challenged solutions. Open Dent J. 2017;11:312-33.

11. Anderson CA, Curzon ME, Van Loveren C, Tatsi C, Duggal MS. Sucrose and dental caries: a review of the evidence. Obes Rev. 2009;10(Suppl 1):41-54.

12. Diaz-Garrido N, Lozano C, Giacaman RA. Frequency of sucrose exposure on the cariogenicity of a biofilm-caries model. Eur J Dent. 2016;10(3):345-50.

13. Gupta P, Gupta N, Pawar AP, Birajdar SS, Natt AS, Singh HP. Role of sugar and sugar substitutes in dental caries: a review. ISRN Dent. 2013;2013: 519421

14. Moye ZD, Zeng L, Burne RA. Fueling the caries process: carbohydrate metabolism and gene regulation by Streptococcus mutans. J Oral Microbiol. 2014;6. https://doi.org/10.3402/jom.v6.24878

15. Nishikawara F, Katsumura S, Ando A, Tamaki Y, Nakamura Y, Sato K, et al. Correlation of cariogenic bacteria and dental caries in adults. J Oral Sci. 2006;48(4):245-51.

16. Flemming HC, Wingender J. The biofilm matrix. Nat Rev Microbiol. 2010;8(9): 623-33.

17. Li Z, Xiang Z, Zeng J, Li Y, Li J. A GntR family transcription factor in Streptococcus mutans regulates biofilm formation and expression of multiple sugar transporter genes. Front Microbiol. 2018;9:3224.

18. Nwodo UU, Green E, Okoh Al. Bacterial exopolysaccharides: functionality and prospects. Int J Mol Sci. 2012;13(11):14002-15.

19. Yang J, Wei W, Pi S, Ma F, Li A, Wu D, et al. Competitive adsorption of heavy metals by extracellular polymeric substances extracted from Klebsiella sp. J1. Bioresour Technol. 2015;196:533-9.

20. Tischler AH, Lie L, Thompson CM, Visick KL. Discovery of calcium as a biofilm-promoting signal for Vibrio fischeri reveals new phenotypes and underlying regulatory complexity. J Bacteriol. 2018;200(15):e00016-8.

21. Cheng X, Liu J, Li J, Zhou X, Wang L, Liu J, et al. Comparative effect of a stannous fluoride toothpaste and a sodium fluoride toothpaste on a multispecies biofilm. Arch Oral Biol. 2017;74:5-11.

22. Ren Z, Kim D, Paula AJ, Hwang G, Liu Y, Li J, et al. Dual-targeting approach degrades biofilm matrix and enhances bacterial killing. J Dent Res. 2019; 98(3):322-30.

23. Leitao TJ, Tenuta LM, Ishi G, Cury JA. Calcium binding to $S$. mutans grown in the presence or absence of sucrose. Braz Oral Res. 2012;26(2):100-5.

24. Leitao TJ, Cury JA, Tenuta LMA. Kinetics of calcium binding to dental biofilm bacteria. PLoS One. 2018;13(1):e0191284

25. Abdallah MN, Eimar H, Bassett DC, Schnabel M, Ciobanu O, Nelea V, et al. Diagenesis-inspired reaction of magnesium ions with surface enamel mineral modifies properties of human teeth. Acta Biomater. 2016;37:174-83.

26. Passos VF, Rodrigues LKA, Santiago SL. The effect of magnesium hydroxidecontaining dentifrice using an extrinsic and intrinsic erosion cycling model. Arch Oral Biol. 2018:86:46-50

27. Selow MLC, Lunelli F, Vieira I, Sotta MD, Martins WDB, Ignácio SA, et al. Analysis of zinc concentration in the saliva of individuals at different age ranges. Rev Odonto Cienc. 2016;31(1):12-5.

28. Fatima T, Haji Abdul Rahim ZB, Lin CW, Qamar Z. Zinc: a precious trace element for oral health care? J Pak Med Assoc. 2016;66(8):1019-23.

29. Lynch RJ. Zinc in the mouth, its interactions with dental enamel and possible effects on caries; a review of the literature. Int Dent J. 2011; 61(Suppl 3):46-54.

30. Kalesinskas P, Kacergius T, Ambrozaitis A, Peciuliene V, Ericson D. Reducing dental plaque formation and caries development. A review of current methods and implications for novel pharmaceuticals. Stomatologija. 2014; 16(2):44-52

31. Yan P, Xia JS, Chen YP, Liu ZP, Guo JS, Shen Y, et al. Thermodynamics of binding interactions between extracellular polymeric substances and heavy metals by isothermal titration microcalorimetry. Bioresour Technol. 2017;232:354-63.

32. Dziewulska A, Janiszewska-Olszowska J, Bachanek T, Grocholewicz K. Salivary mineral composition in patients with oral cancer. Magnes Res. 2013;26(3): 120-4.

33. Van Nieuw AA, Bolscher JG, Veerman EC. Salivary proteins: protective and diagnostic value in cariology? Caries Res. 2004;38(3):247-53.
34. Arifa MK, Ephraim R, Rajamani T. Recent advances in dental hard tissue Remineralization: a review of literature. Int J Clin Pediatr Dent. 2019;12(2): 139-44.

35. Belstrom D. The salivary microbiota in health and disease. J Oral Microbiol. 2020;12(1):1723975.

36. Koo H, Falsetta ML, Klein MI. The exopolysaccharide matrix: a virulence determinant of cariogenic biofilm. J Dent Res. 2013;92(12):1065-73.

37. Song B, Leff LG. Influence of magnesium ions on biofilm formation by Pseudomonas fluorescens. Microbiol Res. 2006;161(4):355-61.

38. Baker MG, Lalonde SV, Konhauser KO, Foght JM. Role of extracellular polymeric substances in the surface chemical reactivity of Hymenobacter aerophilus, a psychrotolerant bacterium. Appl Environ Microbiol. 2010;76(1):102-9.

39. Wang J, Li Q, Li MM, Chen TH, Zhou YF, Yue ZB. Competitive adsorption of heavy metal by extracellular polymeric substances (EPS) extracted from sulfate reducing bacteria. Bioresour Technol. 2014;163:374-6.

40. Holland IB, Jones HE, Campbell AK, Jacq A. An assessment of the role of intracellular free Ca2+ in E. coli. Biochimie. 1999;81(8-9):901-7.

41. McLaughlin SB, Wimmer R. Tansley review no. 104, calcium physiology and terrestrial ecosystem processes. New Phytol. 1999;142(3):373-417.

42. Wang T, Flint S, Palmer J. Magnesium and calcium ions: roles in bacterial cell attachment and biofilm structure maturation. Biofouling. 2019;35(9): 959-74.

43. Rose RK. Competitive binding of calcium, magnesium and zinc to streptococcus sanguis and purified S. sanguis cell walls. Caries Res. 1996; 30(1):71-5.

44. Mohammed NR, Lynch RJ, Anderson P. Inhibitory effects of zinc ions on enamel demineralisation kinetics in vitro. Caries Res. 2015;49(6):600-5.

45. Kahm M, Hasenbrink G, Lichtenberg-Frate H, Ludwig J, Kschischo M. Grofit: fitting biological growth curves with R. J Stat Softw. 2010;33(7):1-21.

46. DuBois M, Gilles KA, Hamilton JK, Rebers PA, Smith FG. Colorimetric method for determination of sugars and related substances. Anal Chem. 1956;28(3): 350-6.

\section{Publisher's Note}

Springer Nature remains neutral with regard to jurisdictional claims in published maps and institutional affiliations.

Ready to submit your research? Choose BMC and benefit from:

- fast, convenient online submission

- thorough peer review by experienced researchers in your field

- rapid publication on acceptance

- support for research data, including large and complex data types

- gold Open Access which fosters wider collaboration and increased citations

- maximum visibility for your research: over $100 \mathrm{M}$ website views per year

At BMC, research is always in progress.

Learn more biomedcentral.com/submissions 